\title{
ŠUOLIO IŠ VIETOS AUKŠČIO VERTINIMO SKIRTINGAIS METODAIS PALYGINIMAS
}

\author{
Kazimieras Muckus \\ Lietuvos kūno kultūros akademija, Kaunas, Lietuva
}

\begin{abstract}
Kazimieras Muckus. Profesorius habilituotas biomedicinos mokslų daktaras. Lietuvos kūno kultūros akademijos Sporto biomechanikos, informatikos ir inžinerijos katedros vedėjas. Mokslinių tyrimų kryptys — biomechaninių sistemų kūrimas, tyrimas ir tobulinimas; sportininkų ir neigaliujų fizinių gebèjimų biomechaninis tyrimas.
\end{abstract}

\section{SANTRAUKA}

Šio tyrimo tikslas - išsiaiškinti, ar šuolio aukštis, apskaičiuotas iš lèkimo trukmés, gali būti vartojamas žmoniu šoklumui vertinti. Kèleme tokius uždavinius: 1) ištirti, kaip siejasi šuolio aukščio juvertis, nustatytas iš žemès reakcijos jègos ir lèkimo trukmès; 2) nustatyti daroma paklaidq vertinant šuolio aukštţ iš lèkimo trukmès. Išanalizavome 116 šuolio dinamogramu. Iš ju 80 atsitiktinai parinktos antro kurso studentu, 36 - jaunimo rinktinés rankininku. Šuoliai buvo atliekami pritupiant, rankos laikomos ant klubu. Kojos per kelius sulenkiamos $90^{\circ} \mathrm{kampu}$. Rankininkai turëjo pašokti kuo aukščiau, tuo tarpu studentams nekèleme šio reikalavimo, kadangi tyrimo uždavinys buvo ne palyginti atskiru tiriamuju grupiu šoklumo rezultatus, o nustatyti, kaip šuolio dinamogramos vieni dydžiai siejasi su kitais. Šuoliai buvo atliekami ant jegos plokštès MA-1, kuria registravome žemés reakcijos jègos vertikaliaja dedamaja. Vertinome tokius dydžius: lèkimo trukmę; vertikaluji masès centro (MC) greiti atitrūkimo nuo žemés momentu; MC pakilimq atitrūkimo nuo žemès momentu $\left(s_{a}\right)$; šuolio aukšti, surandamq dukart integruojant jẻgos kreivę $\left(h_{F}\right)$; šuolio aukštti, surandama iš lékimo trukmès $\left(h_{\text {lek }}\right)$. Tyrimo rezultatai parodé, kad $h_{\text {lek }}$ yra vidutiniškai $14,1 \mathrm{~cm}$ mažesnis už $h_{\mathrm{F}}$ Š artima 13,8 cm. Regresinè analize parodè, kad abiem büdais rastas šuolio aukštis labai priklauso nuo MC pakilimo atitrūkimo nuo žemés momentu, t. y. aukščiau šokant daugiau pakeliamas ir kulnas. Šuolio aukštis, apskaičiuotas iš lèkimo laiko, labai gerai koreliuoja su aukščiu, nustatytu integruojant jègos kreivę $(r=0,95 ; p<0,001)$. Atlikę liekamuju paklaidu analize gavome, $k a d h_{F} 95 \%$ prognozés intervalas yra \pm 0,100 $\mathrm{m}$. Taigi pasikliaudami $95 \%$ galime teigti, kad pagal regresijos lygti suradus šuolio aukšsti $h_{\mathrm{F}}$, jis nuo $h_{l e k}$ skirsis $\pm 10 \mathrm{~cm}$. Išvada: šuolio aukščio įvertinimas iš lèkimo trukmès yra labai netikslus, ir šis büdas negali būti taikomas vertinant sportininkų šoklumq.

Raktažodžiai: vertikalus šuolis, palyginimas, metodai, šuolio aukštis.

\section{IVADAS}

$\mathrm{P}$ astaruoju metu izvairių šakų sportininkų (krepšininku, rankininku, tinklininku, gimnastų ir kt.) fiziniu gebejjimų vertinimui dažnai taikomas šuolio aukštyn iš vietos testas (Bosco et al., 1983 b; Muckus ir kt., 2000; Muckus ir Skarbalius, 2000; Linthorne, 2001). Yra daug šio testo variantų: a) šuolis iš stovimos padèties pritupiant, kai rankos ant klubų; b) šuolis iš stovimos padèties pritupiant ir rankų mostu; c) šuolis iš pradinès padèties pritūpus; d) šuolis nuo pakylos; e) kartotiniai šuoliai ant kontaktinės plokštės
„Ergojump“ (Junghans GMBH—Schramberg, FRG) ir kt. Visi šie testai naudojami ir yra naudingi ivvertinant tam tikras žmogaus gebas. Kiekvienas iš jų turi atitinkamas taikymo sritis. Pavyzdžiui, kontaktinė plokštė „Ergojump“ skirta apytikriam anaerobiniam darbingumui vertinti per treniruotes (Bosco et al., 1983 a).

Šuolio aukšti galima nustatyti keliais būdais: a) registruojant žemės reakcijos jègos kreivę (dinamogramą) šuolio metu; b) filmuojant sportininką, atliekantị šuolị; c) naudojant specialų įrengini 
šuolio aukščiui matuoti; d) iš lèkimo laiko ir kt. Naudojant kontaktinę plokštę, šuolio aukštis apskaičiuojamas iš lèkimo laiko.

Pastaruoju metu pasirodo mokslinių straipsnių, kuriuose šoklumas (šuolio aukštyn iš vietos rezultatas) vertinamas netinkamai, šuolio aukštį apskaičiuojant iš lèkimo trukmès (Mujika et al., 2000; Mickevičienè ir kt., 2005; Rudas, Skurvydas, 2005) ar net iš šuolio aukščio vertinama dinaminè jejga (Kraemer, Newton, 1994), kuri nėra susijusi su šuolio aukščiu.

Nors yra nemažai darbų, vertinančių šuolio aukščio matavimą skirtingais metodais (Hatze, 1998; Adamec et al., 1998; Aragon, 2000), tačiau išsamesnè analizè, kodèl skiriasi įvairiais metodais nustatytos šuolio aukščio vertės, neatlikta.

Šio tyrimo tikslas - išsiaiškinti, ar šuolio aukštis, apskaičiuotas iš lèkimo trukmès, gali būti naudojamas žmonių šoklumui vertinti. Savo tyrimu kèlėme tokius uždavinius:

1. Ištirti, kaip siejasi šuolio aukščio i̇vertis, nustatytas iš žemės reakcijos jẻgos vertikalios dedamosios ir lèkimo trukmès.

2. Nustatyti daromą paklaidą, vertinant šuolio aukšti iš lèkimo trukmès.

\section{METODIKA}

Šuoliai buvo atliekami ant jègos plokštès MA1, kuria registravome žemės reakcijos jègos vertikaliają dedamają. Pastaroji paverčiama į elektrini signalą - itampą, tiesiai proporcingą atramos reakcijos jègos dydžiui. Šis signalas keitikliu analogas / kodas (CYDAS-1402, Cyber Research, JAV) ivedamas i kompiuterio atminti. Signalui analizuoti naudojome anksčiau aprašytą programinę irangą (Muckus ir Kriščiukaitis, 1998; Muckus ir kt., 2000). Analogiški jègos kreivès analizès metodai naudojami atliekant šuolius ant KISTLER plokštès (BioWare Performance Software Version 3.0 Type 2812A2-3. Operating Instruction. Kistler Instrumente AG Winterthur.)

Išanalizavome 116 šuolio dinamogramų. Iš jų 80 atsitiktinai parinktos antro kurso studentu, 36 - jaunimo rinktinès rankininku. Šuoliai buvo atliekami pritūpus laikant rankas ant klubų, kojos per kelius sulenkiamos $90^{\circ} \mathrm{kampu}$. Rankininkai turejjo pašokti kuo aukščiau, tuo tarpu studentams nekèlėme šio reikalavimo, kadangi tyrimo uždavinys buvo ne palyginti atskirų tiriamuju grupių šoklumo rezultatus, o nustatyti, kaip vieni šuolio dinamogramos dydžiai siejasi su kitais.
Tiriamųu ūgio aritmetinis vidurkis $181,3 \pm 9,87 \mathrm{~cm}$, svorio $-71,7 \pm 10,8 \mathrm{~kg}$.

Iš registruojamos šuolio į aukštị atramos reakcijos jègos kreivès (dinamogramos) apskaičiuojami šuolio kinematiniai ir dinaminiai dydžiai.

Jègos plokštę slegianti jèga $F$ proporcinga kūno judejjimo pagreičiui $a: F=m(a+g)$, čia $g$ - laisvojo kritimo pagreitis. Turédami jègos kreivę, galime surasti kūno masès centro (MC) vertikaluji greiti ir poslinkị šuolio metu. Integruodami jègos kreivę, randame atramos reakcijos jègos impulsą $S(t)$ :

$$
S(t)=\int_{0}^{t}[F(t)-G] d,
$$

čia $F(t)$ - atramos reakcijos jèga, $G-$ kūno sunkis. Jègos impulsą $S(t)$ dalydami iš masès $m$ randame greitit $v(t)$ :

$$
v(t)=\frac{S(t)}{m},
$$

Integruodami greičio grafika, gauname MC vertikaluji poslinki $s(t)$ šuolio metu:

$$
s(t)=\int_{0}^{t} v(t) d
$$

1 paveiksle parodyta atramos reakcijos jègos, kūno MC greičio ir poslinkio grafikai tiriamajam A. B. atliekant šuoli aukštyn iš vietos.

Iš šuolio aukštyn jègos, greičio ir poslinkio dydžių galima rasti kitus dydžius, apibūdinančius šuolio atlikimą. Mes vertinome tokius dydžius:

- $t_{\text {lek }}$ - lèkimo trukmę;

- $v_{a t}$ - vertikaluji MC greiti atitrūkimo nuo žemès momentu;

- $s_{a t}$ - MC pakilimą atitrūkimo nuo žemès momentu;

- $h_{F}$ - šuolio aukšti, surandamą dukart integruojant jëgos kreivę;

- $h_{l e k k}$ - šuolio aukšti, surandamą iš lèkimo trukmès;

- $m$ - kūno masę.

Pritūpti pradedama tada, kai jègos kreivè atsilenkia žemyn nuo svorio linijos laiko momentu $t_{0}$ (1 pav.), o baigiama laiko momentu $t_{1}$, kai greitis iš neigiamo pereina į teigiamą. Pritupiant tiesiamieji kojų raumenys susitraukia ekscentriškai, kūno masès centras leidžiasi žemyn, dèl to greitis yra neigiamas. 


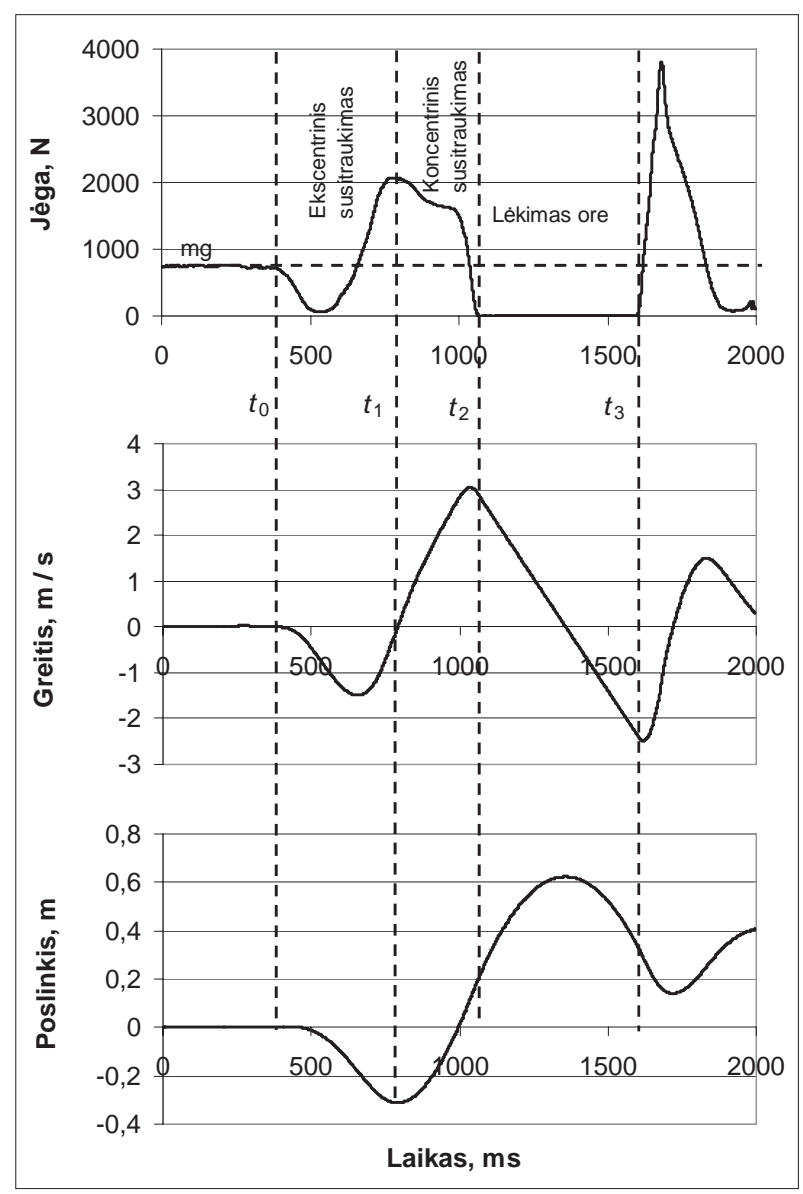

1 pav. Atramos reakcijos vertikalios dedamosios $F, M C$ vertikalaus greičio $v$ ir poslinkio $s$ kitimas atliekant šuolị aukštyn iš vietos pritūpus

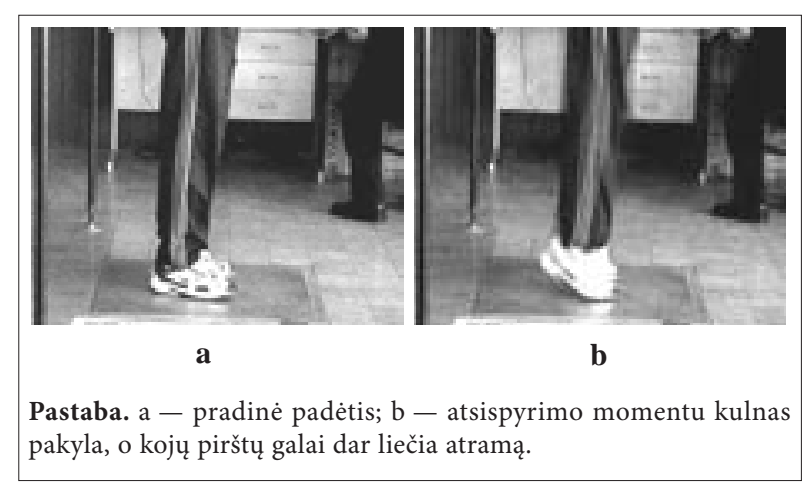

2 pav. Kojų padètis šokant aukštyn iš vietos

Atsispiriant greitis yra teigiamas ir pasiekia maksimalią reikšmę. Atsispirti pradedama laiko momentu $t_{1}$ greičiui pereinant iš neigiamo i teigiamą, o baigiama atitrūkimo nuo atramos momentu $t_{2}$. Atsispiriant raumenys susitraukia koncentriškai.

Lèkimas $\left(t_{l e k k}\right)$ tęsiasi tol, kol žmogaus kūnas pakilęs virš atramos. Pasibaigus lèkimui, prasideda pritūpimas, kurio metu registruojamas smūgis $\mathfrak{i}$ atramą. Ši kreivès dalis paprastai neanalizuojama.
Iš MC greičio grafiko surandamas greitis atitrūkimo nuo plokštės momentu $\left(v_{a t}\right)$. Pastarasis yra vienas iš svarbiausių kinematinių dydžių. Nuo jo priklauso MC pakilimas šuolio metu. Atitrūkus nuo atramos, galioja kūnų laisvojo kritimo dèsniai, ir MC greitis gali būti apskaičiuojamas pagal formulę: $v=v_{a t}-g t$.

Iš MC poslinkio grafiko surandamas MC pakilimas atitrūkimo nuo plokštės metu $\left(s_{a t}\right)$ ir šuolio aukštis $\left(h_{F}\right)$. Atsispyrimo momentu kulnas yra pakilęs, o pèdos priekis dar liečia atramą (2 pav.), todèl atitrūkimo nuo atramos momentu registruojamas MC pakilimas, apytikriai lygus kulno pakilimui nuo atramos. Dažnai šuolio aukštis apskaičiuojamas iš lèkimo trukmès $t_{l e k k}$ ir kūnu laisvojo kritimo pagreičio:

$$
h=\frac{g_{l e k}^{2}}{8} \text {, (4) }
$$

Pagal šią formulę apskaičiuotas šuolio aukštis visada bus mažesnis už tikraji, kadangi neįskaitomas pradinis MC pakilimas atitrūkimo nuo plokštès momentu.

Tyrimo duomenų statistiniam apdorojimui buvo taikomas Microsoft EXCEL Data Analysis programų paketas.

\section{REZULTATAI}

Visų tiriamujų ir atskirai rankininkų šuolio aukštyn iš vietos matuotų dydžių vertès pateiktos lentelèje.

Šuolio aukštị vertinome dviem būdais: a) dukart integruodami jejgos kreivę; b) apskaičiuodami iš lėkimo fazès trukmès. Pirmu atveju nustatyta šuolio aukščio vidutinè verte buvo $36,9 \pm 16,2 \mathrm{~cm}$, antruoju $-22,8 \pm 9,4 \mathrm{~cm}$ (lent.). Taigi šuolio aukštis apskaičiuotas skirtingais metodais skiriasi vidutiniškai $14,1 \mathrm{~cm}$. Ši dydžio vertè artima MC pakilimui atitrūkimo nuo žemès momentu $s_{a t}-13,8 \mathrm{~cm}$. Galima būtų daryti išvadą kad norint surasti tikrają šuolio aukščio vertę prie apskaičiuotos iš lėkimo fazès trukmès $h_{l e k}$ reikia pridèti $14 \mathrm{~cm}$, t. y. turètų galioti lygybè:

$$
h_{F}=h_{\text {lek }}+0, \mathbb{\#} \text {, }
$$

Visgi ši lygybė gali būti tiksli tik tuomet, kai $s_{a t}$ nepriklauso nuo $h_{F}$ ir $h_{l e k \text {. }}$

Norèdami nustatyti ryši tarp šių dydžių, atlikome regresinę analizę. 3 paveiksle parodyta koreliacinè priklausomybè tarp dviem būdais surasto 


\begin{tabular}{|c|c|c|c|c|c|c|c|}
\hline \multirow{2}{*}{ Dydis } & \multicolumn{3}{|c|}{ Visi tiriamieji } & \multicolumn{3}{|c|}{ Rankininkai } & \multirow{2}{*}{$\begin{array}{l}\text { Lentelè. Šuolio aukštyn iš } \\
\text { vietos matuotų dydžių ver- } \\
\text { tès }\end{array}$} \\
\hline & $\bar{x}$ & s & $R$ & $\bar{x}$ & $s$ & $R$ & \\
\hline$t_{l e \dot{k}, \mathrm{~ms}}$ & 421 & 93 & $229-566$ & 518 & 24 & $480-566$ & \multirow{6}{*}{$\begin{array}{l}\text { Pastaba. } \bar{X}-\text { aritmetinis } \\
\text { vidurkis, } s-\text { standartinis } \\
\text { nuokrypis, } R-\text { imties plotis. }\end{array}$} \\
\hline$v_{a t}, \mathrm{~m} / \mathrm{s}$ & 2,06 & 0,52 & $1,05-2,93$ & 2,66 & 0,16 & $2,37-2,93$ & \\
\hline$s_{a t}, \mathrm{~m}$ & 0,138 & 0,055 & $0,038-0,239$ & 0,188 & 0,034 & $0,101-0,239$ & \\
\hline$h_{F}, \mathrm{~m}$ & 0,369 & 0,162 & $0,094-0,628$ & 0,551 & 0,069 & $0,386-0,628$ & \\
\hline$h_{\text {lek, },} \mathrm{m}$ & 0,228 & 0,094 & $0,064-0,393$ & 0,330 & 0,031 & $0,282-0,393$ & \\
\hline m, kg & 71,7 & 10,8 & $51,0-94,9$ & 77,1 & 7,2 & $66,48-91,9$ & \\
\hline
\end{tabular}

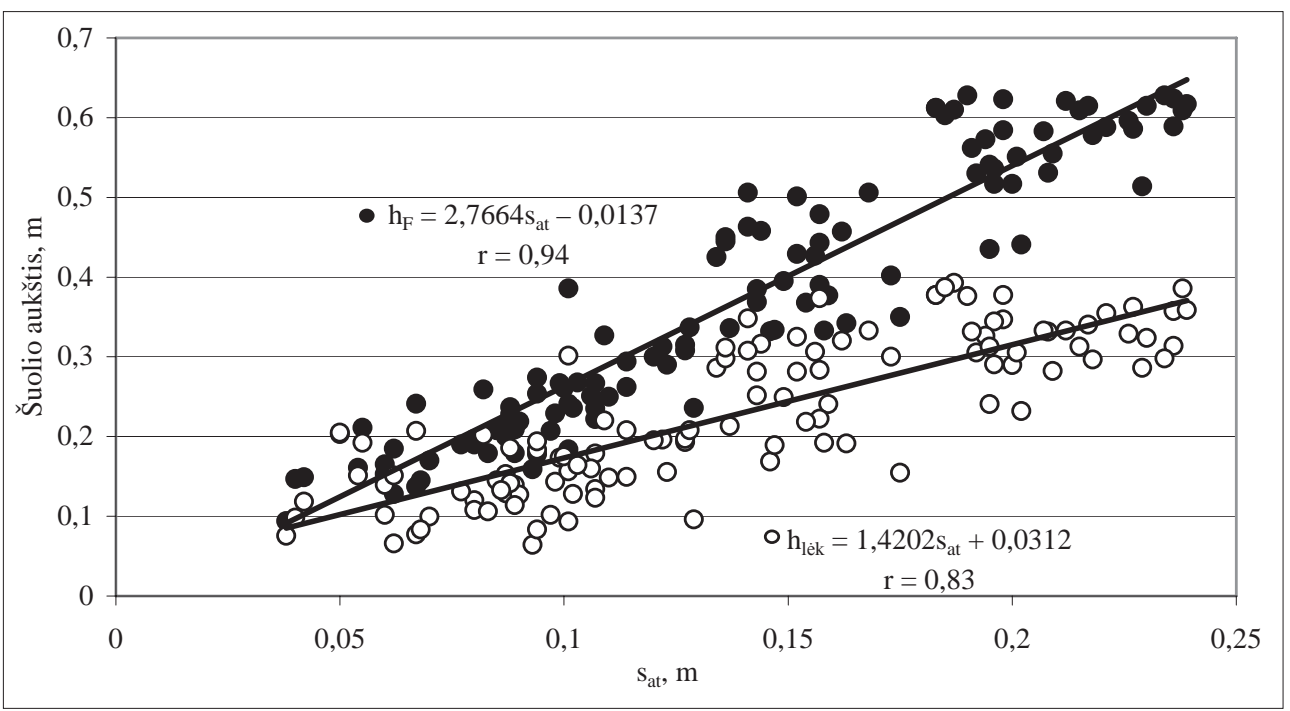

3 pav. Dviem būdais surasto šuolio aukščio ir $s_{a t}$ koreliacinè priklausomybè

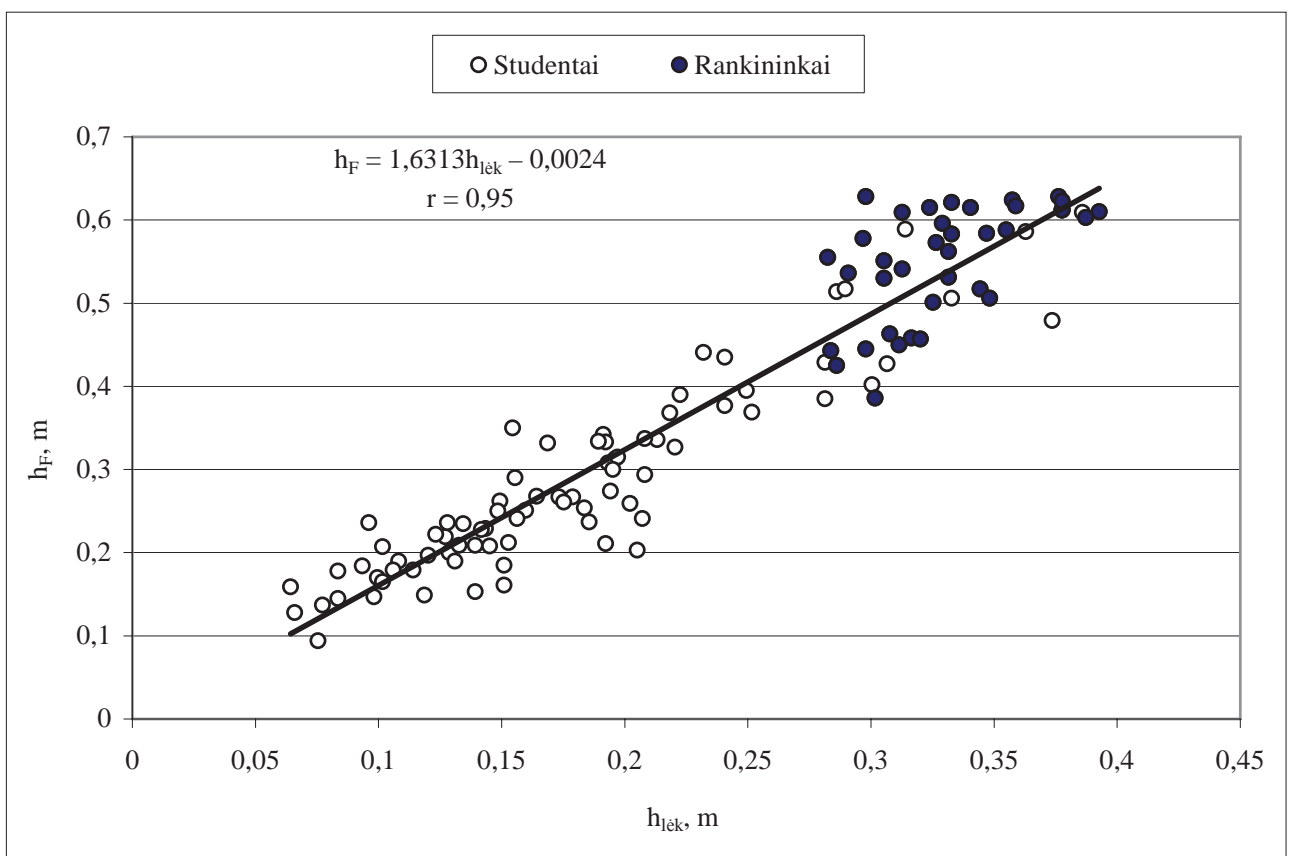

4 pav. Šuolio aukščio, surasto integruojant jègos kreivę, $\boldsymbol{h}_{F}$, ir aukščio, apskaičiuoto iš lèkimo fazès trukmès, $\boldsymbol{h}_{l \dot{k} k}$, koreliacinè priklausomybè bei regresijos tiesé

šuolio aukščio ir $s_{a t}$. Pateiktame grafike aiškiai matyti, kad abiem būdais rastas šuolio aukštis labai priklauso nuo MC pakilimo atitrūkimo nuo žemès momentu, t. y. aukščiau šokant daugiau pakeliamas ir kulnas. Taigi, remiantis išnagrinèta priklausomybe, (5) formulè yra netinkama.

4 paveiksle parodyta koreliacinė priklausomybè tarp dviem būdais surasto šuolio aukščio.
Matome, kad šuolio aukštis, apskaičiuotas iš lèkimo laiko, labai gerai koreliuoja su aukščiu, nustatytu integruojant jègos kreivę ( $\mathrm{r}=0,95$; $\mathrm{p}<0,001)$. Jei besiremtume tik vidutiniais statistikiniais dydžiais, regresijos tiesès lygtis turètu atitikti (5) formulę. Kadangi šuolio aukštis stipriai priklauso nuo kulno pakèlimo atsispyrimo momentu, todèl tiesinès regresijos lygtis, aprašanti 
$h_{F}$ priklausomybę nuo $h_{l e k \text {, }}$ gaunama tokia:

$$
h_{F}=1,6313 h_{l e k}-0,0024 \text { (6) }
$$

Jei darysime prielaida, kad šuolio aukštis, nustatytas integruojant jègos kreivę, yra tikslesnis, tai remiantis (6) lygtimi galima tiksliau surasti tikraji šuolio aukšti iš šuolio aukščio, apskaičiuoto iš lèkimo laiko.

Kyla klausimas, kokia daroma paklaida vertinant šuolio aukštį iš lèkimo trukmès? Atlikę liekamujų paklaidų analizę (Čekanavičius, Murauskas, 2002) gavome, kad $h_{F} 95 \%$ prognozès intervalas yra $\pm 0,100 \mathrm{~m}$. Taigi pasikliaudami $95 \%$ galime teigti, kad pagal (6) regresijos lygti suradus šuolio aukšti $h_{F}$, jis nuo $h_{l e k}$ skirsis $\pm 10 \mathrm{~cm}$ ir tikroji šuolio aukščio vertè bus:

$$
h_{F}=1,6313 h_{l e k}-0,0024 \pm 0,100,(7)
$$

4 paveiksle pažvelgus į rankininkų duomenų koreliacinį lauką matyti, kad jų tarpusavio ryšys yra daug silpnesnis. Koreliacijos koeficientas $\operatorname{tarp} h_{F}$ ir $h_{\text {lek }}$ lygus tik 0,59. Todèl kai tiriama homogeniška grupè (visų tiriamuju šuolio aukštis yra panašus, t. y. mažai skiriasi nuo grupès vidurkio), atskirti tiriamuosius grupès viduje pagal apskaičiuotą iš lèkimo trukmès šuolio aukšti yra negalima.

\section{REZULTATŲ APTARIMAS}

Šuolio aukštis yra svarbiausias dydis vertinant sportininkų šoklumą. Tiksliausiai šuolio aukštis nustatomas iš filmuotos medžiagos arba naudojant specialius įtaisus šuolio aukščiui matuoti (Abalakovo metodas). Visgi dažniausiai šuoliai atliekami ant jëgos arba kontaktinės plokštès. Šiuo atveju šuolio aukštis nustatomas registruojant žemès reakcijos jègos vertikaliają dedamają šuolio metu arba iš lèkimo trukmès.

Yra nemaža darbų, kuriuose lyginamas šuolio aukščio vertinimas skirtingais metodais (Hatze, 1998; Aragon, 2000; Adamec et al., 1998). Dauguma autorių nurodo, kad mažiausiai tikslus metodas yra šuolio aukščio apskaičiavimas iš lèkimo trukmès. J. Adamec (1998) rado, kad iš lėkimo trukmės surastas šuolio aukštis yra apie $0,13 \mathrm{~m}$ mažesnis, negu nustatytas atliekant judesio kinematinę analizę. Autorius ši skirtumą aiškina kulkšnies pakèlimu baigiamojoje atsispyrimo fazèje. Mes šuolio aukšti vertinome dviem būdais: a) dukart integruodami jejgos kreivę; b) apskaičiuodami iš lèkimo trukmès. Pirmu būdu nustatyta šuolio aukščio vidutinè vertẻ buvo vidutiniškai 0,14 m didesnè nei antruoju. Ši dydžio vertė artima MC pakilimui atitrūkimo nuo žemès momentu $s_{a t}-13,8 \mathrm{~cm}$. Taigi šuolio aukštis, apskaičiuotas iš lèkimo laiko, dèl kulkšnies pakilimo (2 pav.) yra apie 13-14 cm mažesnis už tikraji šuolio aukštị.

Mes, skirtingai nei kiti autoriai, tyrème, kokia yra koreliacinè priklausomybė tarp skirtingais būdais įvertinto šuolio aukščio ir kulkšnies pakilimo atitrūkimo nuo žemės momentu. Kaip parodè tyrimo rezultatai, šuolio aukštis gerai koreliuoja su kulkšnies pakilimu - kuo aukštesnis šuolis, tuo didesnis kulno pakilimas (3 pav.). Tai reiškia, kad norint surasti tikslesni šuolio aukštị, nepakanka prie $h_{\text {lek }}$ pridèti $0,14 \mathrm{~m}$.

Noredami išsamiau ištirti priklausomybę tarp skirtingais būdais įvertinto šuolio aukščio, atlikome regresinę analizę. Suradę tiesinès regresijos lygti (6), atlikome liekamuju paklaidų analizę (Čekanavičius, Murauskas, 2002) ir gavome, kad pasikliaudami 95\% galime teigti: pagal (6) regresijos lygtị suradus šuolio aukšti $h_{F}$, jis nuo $h_{\text {lèk }}$ skirsis $\pm 10 \mathrm{~cm}$. Taigi tiriant homogenišką grupę (visų tiriamujų šuolio aukštis yra panašus, t. y. mažai skiriasi nuo grupès vidurkio) atskirti tiriamuosius grupès viduje pagal apskaičiuotą iš lèkimo trukmès šuolio aukšti yra negalima. Tai akivaizdžiai rodo 4 paveikslas, kuriame matyti, kad tirtų rankininkų $h_{F}$ ir $h_{l e k}$ silpnai koreliuoja.

\section{IŠVADOS}

Apibendrinus tyrimo rezultatus, galime padaryti išvadą, kad šuolio aukščio vertinimas iš lèkimo trukmės yra labai netikslus, ir šis būdas negali būti taikomas vertinant sportininkų šoklumą.

\section{LITERATŪRA}

Adamec, J., Novotny, P., Vaverka, F. (1998). A comparison of various methods for the assessment of vertical jump height. Proceedings of the 16th Symposium of thr International Society of Biomechanics in Sports, Konstanz, July 21-25. Prieiga per interneta: http://www. isbs.uni-konstanz.de/Abstracts/j.adamec.pdf
Aragon, L. F. (2000). Evaluation of four vertical jump tests: Methodology, reliability, validity, and accuracy. Measurement in Physical Education and Exercise Science, 4 (4), 215-228. Prieiga per internetą: doi:10.1207/S15327841MPEE0404_2

BioWare Performance Software Version 3.0 Type 
2812A2-3. Operating Instruction. Kistler Instrumente AG Winterthur.

Bosco, C., Luhtanen, P., Komi, P.V. (1983 a). A simple method for measurement of mechanical power in jumping. European Journal of Applied Physiology and Occupational Physiology, 50 (2), 273-82.

Bosco, C., Mognoni, P., Luhtanen, P. (1983 b). Relationship between isokinetic performance and ballistic movement. European Journal of Applied Physiology and Occupational Physiology, 51 (3), 357-64.

Čekanavičius, V., Murauskas, G. (2002). Statistika ir jos taikymai. D. II. Vilnius: TEV.

Hatze, H. (1998). Validity and reliability of methods for testing vertical jumping performance. Journal of Applied Biomechanics, 14, 127-140.

Kraemer, W. J., Newton, R. U. (1994). Training for improved vertical jump. Sports Science Exchange, 7 (6). Prieiga per internetą: http://www.gssiweb.com/reflib/refs/26/ d0000000200000067.cfm?pid=38

Linthorne, N. P. (2001). Analysis of standing vertical jumps using a force platform. American Journal of Physiology, 69 (11), 1198-1204.
Mickevičienė, D., Mamkus, G., Stanislovaitis, A., Skurvydas, A. (2005). Šoklumo ištvermès treniruočių poveikis nervų ir raumenų sistemų nuovargio ir atsigavimo kaitai. Ugdymas. Kūno kultūra. Sportas, 1 (55), 26-33.

Muckus, K., Kriščiukaitis, A. (1998). Dinamografiniu parametru ivvertinimo kompiuterinė sistema. Biomedicinine inžinerija: tarptautinès konferencijos medžiaga (pp. 146149). Kaunas: KTU.

Muckus, K., Kriščiukaitis, A., Zdanavičienè, S. (2000). Evaluation of human psychomotor performance using ground reaction force analysis. Scientific Proceedings of Riga Technical University: Computer Science. Technologies of Computer Control. Riga: RTU. P. 12-20.

Muckus, K., Skarbalius, A. (2000). Rankininkų psichomotorinès reakcijos ypatumai. Ugdymas. Kūno kultūra. Sportas, 2 (35), 42-47.

Mujika, I., Padilla, S., Ibanez, J., Izquierdo, M. and Gorostiaga, E. (2000). Creatine supplementation and sprint performance in soccer players. Medicine \& Science in Sports \& Exercise, 32 (2), 518-525.

Rudas, A., Skurvydas, A. (2005). Jaunesniojo mokyklinio amžiaus mergaičių šoklumo kaita per du mènesius. Ugdymas. Kūno kultūra. Sportas, 1 (55), 43-48.

\title{
COMPARISON OF VARIOUS METHODS FOR THE ASSESSMENT OF VERTICAL JUMP HEIGHT
}

\author{
Kazimieras Muckus \\ Lithuanian Academy of Physical Education, Kaunas, Lithuania
}

\begin{abstract}
The aim of the study — to investigate the relationship between the jump height defined from the ground reaction force-time curve and the flight time, also to establish possible error, when the jump height is determined only from the flight time. The analysis of 116 dynamograms was performed. 80 dynamograms were of the randomly selected second grade students, 36 - of the handball players from the junior team. Countermovement jumps were performed making a knee-bend with arms placed on the hips. The angle of the knee flexion was $90^{\circ}$. The handball players had to jump as high as they could. This kind of the instruction was not given to the students because our aim was to investigate the relation between dynamogram parameters, but not to compare the jump results of the groups. The jumps were performed on the force plate MA-1; the vertical component of the ground reaction force was recorded. The flight time, the vertical velocity of the center of mass (MC) at the instant of the takeoff, the lift of MC at the instant of the takeoff $\left(s_{a t}\right)$, the jump height computed from force-time curve $\left(h_{F}\right)$, the jump height determined from the flight time $\left(h_{l e k}\right)$ were analyzed. The results of the study showed that $h_{l e k}$ is on the average $14.1 \mathrm{~cm}$ less higher than $h_{F}$. This value is approximate $s_{a t}-13.8 \mathrm{~cm}$. The regression analysis showed that jump height determined by both methods is closely related to the lift of MC at the instant of the takeoff, that is, when jump is higher, the heel is raised more. The jump height, calculated according to the flight time is closely related to the jump height determined by force curve integration $(\mathrm{r}=0.95 ; \mathrm{p}<0.001)$. The analysis of the residual errors showed that $h_{F}$ $95 \%$ interval of prediction is $\pm 0.100 \mathrm{~m}$. Hence we may predicate in $95 \%$ that the jump height $h_{F}$ will differ from $h_{l e k} \pm 10 \mathrm{~cm}$ according to regression equation. Conclusion: the determination of the jump height from the flight time is very inaccurate and this method can not be used for sportsmen's spring assessment.
\end{abstract}

Keywords: countermovement jump, comparison, methods, jump height.

Gauta 2005 m. birželio 29 d.

Received on June, 29, 2005

Priimta 2005 m. lapkričio 16 d.

Accepted on November 16, 2005
Kazimieras Muckus

Lietuvos kūno kultūros akademija

(Lithuanian Academy of Physical Education)

Sporto g. 6, LT-44221 Kaunas

Lietuva (Lithuania)

Tel +370 37302635

E-mail muckusk@kalnieciai.lt 